\title{
Usage of Waterborne Acrylate Anticorrosion Systems for Ecological Environment
}

Jiri Votava, Vojtech Kumbar

Faculty of AgriSciences, Mendel University in Brno. Zemedelska 1/1665, 61300 Brno. Czech Republic. E-mail: jiri.votava@mendelu.cz,vojtech.kumbar@mendelu.cz

\begin{abstract}
All technical metals used not only in agriculture are subject to degradation processes, there are distinguished two main types: mechanical abrasion and physical-chemical degradation (corrosion). In order to lower abrasion of a machine part, it is necessary to use appropriate technical materials as well as an appropriate heat treatment. To minimize losses caused by corrosion, an appropriate anticorrosion system has to be used. This paper evaluates corrosion and mechanical resistance of waterborne acrylate anticorrosion systems sold on the Czech market. These paints were applied by an air flow technology. Mechanical characteristics of the applied coating were evaluated according to the ČSN EN ISO 4624 (pull-off test for adhesion), ČSN EN ISO 2409 (cross-cut test) and ČSN EN ISO 1520 (cupping test). As used anticorrosion systems were applied also on zinc-dipped coating, this duplex system was also subject to the mentioned tests. Corrosion resistance of the tested anticorrosion systems was analysed in the salt-spray environment (ČSN EN ISO 9227). Based on the results of the individual tests, there can be characterised adhesion, flexibility and mechanical resistance of waterborne anticorrosion systems as well as a further application on zinc layers. Corrosion tests analyse the process and visual appearance of corrosion attack.
\end{abstract}

Keywords: Corrosion, Ecologic Paints, Paint Tenacity, Wareborne

\section{Acknowledgment}

This study was supported by the project no. TP 4/2014 "Analysis of degradation processes of modern materials used in agricultural technology" and financed by Internal Grant Agency Mendel University in Brno; Faculty of Agronomy.

\section{References}

[1] McELROY, B. (2002). Waterborne coatings rise to the occasion: New technologies meet today's market. Leeds, Metal Finishing, Vol. 100, No. 6, pp. 112-114.

[2] FEKETE, E., LENGYEL, B. (2005). Accelerated testing of waterborne coatings.Progress in Organic Coatings, Vol. 54, No. 3, pp. 211-215.

[3] KOVALČÍK, T., STOULIL, J., SLÁMA, P., VOJTĚCH, D. (2015). The influence of heat treatment on mechanical and corrosion properties of wrought aluminium alloys 2024 and 6064, Manufacturing Technology, Vol. 15, No. 1, pp. 54-61.

[4] ZATKALÍKOVÁ, V., MARKOVIČOVÁ, L., BELAN, J., LIPTÁKOVÁ, T. (2014). Variability of local corrosion attack morphology of AISI 316Ti stainless steel in aggressive chloride environment. Manufacturing Technology, Vol. 14, No. 3, pp. 493-497.

[5] KUSMIC, D., DOBROCKY, D. (2015). Corrosion resistance of plasma nitrided structural steels. Manufacturing Technology, Vol. 15, No. 1, pp. 64-69.

[6] LUPTÁKOVÁ, N., KEBISKOVÁ, J., ANISIMOV, E., BENÁK, M., PEŠLOVÁ, F. (2012). Impact raw material for production zinc oxide in retort furnaces. Source of the Document METAL - Conference Proceedings, 21st International Conference on Metallurgy and Materials, pp. 1521-1526.

[7] LUPTÁKOVÁ, N., PEŠLOVÁ, F., KLIBER, J. (2015). The study and microstructure analysis of zinc and zinc oxide, Metalurgija, Vol. 54, No. 1, pp. 43-46.

[8] CAPRARI, J.J., DI SARLI, A.R., DEL AMO, B. (2000). Zinc phosphate as corrosion inhibitive pigment of waterborne epoxy paints used for steel protection. Pigment and Resin Technology, Vol. 29, No. 1, pp. 16-22.

[9] AMALVY, J.I., AZNAR, A.C., PARDINI, O.R., GUZMAN, G.A.(2002). Waterborne Anticorrosive Systems for Steel Protection-Part 1: Formulation and Testing. Corrosion, Vol. 58, No. 10, pp. 871-880.

[10] GALLIANO, F., LANDOLT, D.(2002). Evaluation of corrosion protection properties of additives for waterborne epoxy coatings on steel.Progress in Organic Coatings, Vol. 44, No. 3, pp. 217-225.

[11] FERNANDEZ-PEREZ, B.M., GONZALEZ-GUZMAN, J.A., GONZALEZ, S., SOUTO, R.M. (2014). Electrochemical impedance spectroscopy investigation of the corrosion resistance of a waterborne acrylic coating containing active electrochemical pigments for the protection of carbon steel.International Journal of Electrochemical Science, Vol. 9, No. 4, 2067-2079. 
[12] GEE, S. (1997). Water-borne coatings for steel.Surface Coatings International, Vol. 80, No. 7, pp. 316-320.

[13] WEGMANN, A. (1997). Chemical resistance of waterborne epoxy/amine coatings.Progress in Organic Coatings, Vol. 32, No. 1-4, pp. 231-239.

[14] VOTAVA, J. (2013). Corrosion resistance of zinc-based systems in nacl environment. Acta Universitatis Agriculturae Et Silviculturae Mendelianae Brunensis, Vol. 61, No.5, pp. 1487-1495.

[15] SERE, P.R., ELSNER, C.I., DI SARLI, A.R. (1998).Corrosion behaviour of two duplex systems in salt spray testing.Corrosion Prevention and Control, Vol. 45, No. 4, pp.109-117.

[16] SERE, P.R., DEYA, C., ELSNER, C.I., DI SARLI, A.R.(2014).Behavior of two eco-compatible duplex systems used in the construction industry against corrosion.International Journal of Adhesion and Adhesives, Vol. 50, pp. $1-6$.

[17] LIPTÁKOVÁ, T., LOVÍŠEK, M., HADZIMA, B. (2015). Parameters affected corrosion and mechanical properties of Al-brasses In: Manufacturing Technology, Vol. 15, No. 4, pp. 587-591.

[18] SVOBODOVÁ, J., CAIS, J., MICHNA, Š., BRŮHA, M. (2013). Research of corrosion properties of Al-Si alloys antimony alloyed. Manufacturing Technology, Vol. 13, No. 3, pp. 404-409.

[19] BARBATO, R., BOI, R., RAGAZZINI, R. (2002). Determination of micro-indentation hardness of organic coatings.VDI Berichte, Vol. 1685, pp. 373-378.

[20] BECK, U., REINERS, G., LERCHE, D., RIETZ, U., NIEDERWALD, H. (2011). Quantitative adhesion testing of optical coatings by means of centrifuge technology. Surface and Coatings Technology, Vol. 205, No. 2, pp. $182-186$.

[21] ČSN EN ISO 4624 Paints and varnishes - Pull-off test for adhesion (2003), 17 p.

[22] ČSN EN ISO 2409 Paints and varnishes - Cross-cut test (2013), 17 p.

[23] ČSN EN ISO 1520 Paint and varnishes - Cupping test (2002), 12 p.

[24] ČSN EN ISO 9227 Corrosion tests in artificial atmospheres - Salt spray tests (2007), $21 \mathrm{p}$.

[25] LUPTAKOVA, N., PESLOVA, F., STODOLA, P., STODOLA, J. (2015). Microstructural study and analysis of hard zinc. Paper presented at the Transport Means - Proceedings of the International Conference, pp. 13-16.

[26] VOTAVA, J. (2013): Corrosion resistance of water-thinnable paint systems.Journal of Central European Agriculture, Vol. 14, No. 4, pp. 1271-1278.

[27] AMBROZ, O., KASPAR, J. (1990).Hot sprays and their usage in the industry. SNTL, Praha, 318 p. (In Czech).

[28] ALMEIDA, E., PEREIRA, D., FIGUEIREDO, O. (1989). The degradation of zinc coatings in salty atmospheres. Progress in Organic Coatings, Vol. 17, No. 2, pp. 175-189.

[29] ALMEIDA, E., SANTOS, D., URUCHURTU, J. (1999). Corrosion performance of waterborne coatings for structural steel. Progress in Organic Coatings, Vol. 37, No. 3-4, pp. 131-140. 